\title{
EFFECTS OF SEAWEED SUPPLEMENTATION TO FATTENING FRIESIAN STEERS RATIONS ON: 1-THE NUTRITIVE VALUE AND RUMEN FERMENTATION Ead, H. M. E. ${ }^{1}$ and Eman H. M. Maklad ${ }^{2}$ \\ 1- Animal Production Res. Inst., Agric. Res. Center, Dokki, Giza, Egypt. 2- Animal Production Dept., Fac. Agric. Mansoura University, Egypt.
}

\begin{abstract}
Three digestibility trials were conducted using three steers for each; which were with average body weight $392 \pm 3.3 \mathrm{~kg}$ and 18 month of age. The experimental rations were formulated as follows: ration 1 (R1) $81.8 \%$ concentrate feed mixture $(\mathrm{CFM})+18.2 \%$ clover hay $(\mathrm{CH})$ (control), ration $2(\mathrm{R} 2): 81.55 \% \mathrm{CFM}+18.05 \% \mathrm{CH}+$ $0.40 \%$ seaweed $(\mathrm{S})$ and ration $3(\mathrm{R} 3): 81.23 \% \mathrm{CFM}+17.87 \% \mathrm{CH}+0.90 \% \mathrm{~S}$.

The results showed that there were no significant effect of feeding the experimental rations on the digestion coefficients for all nutrients and feeding values, but the digestion coefficients of OM, NFE, ADF, cellulose, ADL, NFC, TDN\%, ME (Mcal/kg DM) and NE (Mcal/kg DM) were higher when feeding on R2 or R3 than R1.

The predicted values using net carbohydrate and protein system (CNCPS) showed that the sugar and starch fermentation were 276.6 and $729.4 \mathrm{~g} / \mathrm{d}$, respectively with feeding $R 1,277$ and $731.4 \mathrm{~g} / \mathrm{d}$, respectively for $\mathrm{R} 2$ and 277.6 and $737.2 \mathrm{~g} / \mathrm{d}$, respectively for $\mathrm{R} 3$. The total microbial protein was $1006,1008.4$ and $1014.8 \mathrm{~g} / \mathrm{d}$ when feeding on R1, R2 and R3, respectively.

The mean values of ruminal $\mathrm{pH}$, buffering capacity (BC), VFA's were not significant affected by the different dietary treatments, while the concentration of $\mathrm{NH}_{3}$ $\mathrm{N}(\mathrm{mg} / 100 \mathrm{ml} \mathrm{RL})$ tended to increase $(\mathrm{p}<0.05)$ when animals were fed on R2 or R3 (13.74 and $14.20 \mathrm{mg} / 100 \mathrm{ml} \mathrm{RL}$, respectively) than $\mathrm{R} 1(11.82 \mathrm{mg} / 100 \mathrm{ml} \mathrm{RL}$ ).

The present study showed that, the dry matter intake and nutrients digestibility were improved by supplemented seaweed but the total VFA's was higher with feeding on $81.55 \% \mathrm{CFM}+18.05 \% \mathrm{CH}+0.40 \%$ seaweed $(\mathrm{S})$ than the other rations.
\end{abstract}

Keywords: Friesian steers, seaweed, digestion coefficients and fermentation.

\section{INTRODUCTION}

The risk of acidosis is increased when cattle are fed forages high in non-structural carbohydrates (sugars and starches) with low effective fiber content, such as clovers and young Lucerne (alfalfa) and possibly ryegrass that may not stimulate adequate rumination and salivation, especially when fed in combination with concentrate feeding (Kolver and de Veth, 2002) .

In ruminants, acidosis is defined as the biochemical and physiological stress caused by rapid production and absorption of ruminal organic acids (volatile fatty acids (VFA) and lactic acid) that arise the over consumption of readily fermentable carbohydrates (Britton and Stock, 1986).

The rapid ingestion of high grain diets include a dramatic reduction of ruminal $\mathrm{pH}$ (5.2 or less) (Cooper and Klopfenstein, 1996), increased concentration of VFA's and lactic acid in the rumen (Huntington, 1988) and a significant decline in total protozoa (Hristov et al, 2001). 
In severely acute cases, death may occur within 24 to 72 hours following grain engorgement (Glock and DeGroot, 1998).

For the rumen to work efficiency and effectively the rumen microbes need a steady supply of fermentable energy and degradable protein and most importantly they need a stable rumen pH between 6.0 and $7.0 \mathrm{pH}$ (Russell and Hino, 1985). Within this $\mathrm{pH}$ range the rumen is at its most efficient.

Buffer supplementation of high concentrate diets has been shown to improve or stabilize feed intake and increase animal performance in some studies (Solorzano et al, 1989; Zinn, 1991), but not in others (Coppock et al, 1986).

Aga et al (2000) were used a calcified seaweed as a buffer in continuous culture of rumen contents.

The chemical composition of ordinary seaweed, as from Ascophyllum nodosum, immediately characterizes the material as of low energy content. According to the analytical data the value of seaweed meal must primarily be sought in its content of vitamins, and minerals, among which $\beta$-carotene, tocopherols, some B vitamins, iodine, zinc and potassium are the more important (Scott, 1990). The rational way of using seaweed meal in rations would be to let this component supply the above active substances according to the analytical data and to add the factors lactating to obtain a balanced diet.

Sykes (2009) reported that the seaweed is a totally natural multimineral supplement. Seaweed contains all minerals and trace elements an animal requires for a normal healthy life. The feeding recommendation for finishing cattle is from 100-120 g per day.

On the other hand, Scott (1990) reported that for ration proves equal the normal balanced ration, economic considerations should decide diet is to be preferred.

The objective of this study was to evaluate the effect of supplementing different levels of seaweed concentration in finishing phase of Friesian steers rations on nutrient digestibility and ruminal fermentations.

\section{MATERIALS AND METHODS}

This study was conducted at El-Karada Animal Production Research Station, Animal Production Research Institute, Agricultural Research Center, Ministry of Agriculture in Egypt and Department of Animal Production, Fac. of Agric., Mansoura University.

Three Experimental Rations Were Formulated as Follows:

R1: ration 1: $81.8 \%$ concentrate feed mixture (CFM) + $18.2 \%$ clover hay

$(\mathrm{CH})$ (as a control ration).

R 2: ration 2: $81.55 \% \mathrm{CFM}+18.05 \% \mathrm{CH}+0.40 \%$ seaweed $(\mathrm{S})$

R 3: ration 3: $81.23 \% \mathrm{CFM}+17.87 \% \mathrm{CH}+0.90 \% \mathrm{~S}$.

The CP concentration of tested rations were ranged from 16 to $17 \%$ according to Hunter et al (1999). Steers were individually fed the experimental rations. 
The concentrate feed mixture (CFM) used contained $44 \%$ yellow corn , $23 \%$ soybean meal (44\% protein), $14 \%$ wheat bran, $11.5 \%$ rice bran , $4.5 \%$ molasses, $2 \%$, limestone and $1 \%$ salt.

The clover hay was made from the $3^{\text {rd }}$ cut of Egyptian clover.

The supplement seaweed meal as from Ascophyllum nodosum manufactured by Acadian Sea plants Limited, Canada. The approximate label analysis showed that it contains protein, fiber, carbohydrates, vitamins and minerals.

Management of feeding:

The intake of tested ration by steers was fixed and calculated as the percentage of roughage to concentrate ratio to satisfy their maintenance and production requirements (Ghoneim, 1967).

The CFM fed with or without seaweed was offered to steers at morning. While clover hay $(\mathrm{CH})$ given after consumption of the concentrate. Drinking fresh and clean water was available at all times

Digestibility Trails:

Three digestibility trials were conducted using three steers to determine nutrients digestibility coefficients and nutritive values of the experimental rations. Animals were fed to cover the requirements of fattening steers. Steers were with average body weight $392 \pm 3.3 \mathrm{~kg}$ and 18 month of age. Animals were fed their allowances according to the experimental to assignment of each group. Acid insoluble ash (AIA) was used as a natural marker (Nan Keulen and Young, 1977). Nutrients digestibility was calculated from the equations stated by Schneider and Flatt (1975).

Feces samples were taken from the rectum of each steer twice daily with 12 hours interval during the collection period of each trial (5 days) and dried in a forced air oven at $65^{\circ} \mathrm{C}$ for 48 hours. Dried samples were composted for each animal and representative's samples were taken, ground and kept for chemical analysis.

\section{Chemical Analysis:}

Samples of CFM, CH, S were taken at the beginning of the trials. The composite samples were dried in a forced air oven at $65^{\circ} \mathrm{C}$ for 48 hours, then ground and running the chemical analysis for each. Feces samples were taken from the rectum of each animal twice daily with 12 hours interval at during the collection period of each trial and dried in a forced air oven at $65^{\circ} \mathrm{C}$ for 48 hours. Dried samples were composted for each steer and representative samples were taken, ground and kept for chemical analysis.

Chemical analysis of CFM, CH and S and feces were carried out according to the methods of AOAC (1990), fiber fractions (NDF,ADF ADL, Hemc. and Cell.) was determined according to method of Van Soest, (1982).

At the end of each collection period ruminal fluid samples were taken using rubber stomach tube before offering the morning feed and at 2, 4 and 8 hrs post- feeding from three animals in each treatment. The collected rumen fluid samples were filtered through three layers of gauze without squeezing for the determination of $\mathrm{pH}$, buffering capacity (BC), ammonia- $\mathrm{N}$ and total volatile fatty acids (TVFA's) concentration. Ruminal $\mathrm{pH}$ was estimated by $\mathrm{pH}$ meter (Orion Research, model 201 digital pH meter). Buffering capacity was the milli-equivelaents of $\mathrm{HCl}$ required to bring the $\mathrm{pH}$ of $100 \mathrm{ml}$ rumen liquor to $\mathrm{pH} 4.5$ (Nickolson et al, 1963) determined immediately after sampling. 
Ruminal $\mathrm{NH}_{3}-\mathrm{N}$ was determined according to Conway (1957). The TVFA's were determined by the steam distillation method as described by Warner (1964).

\section{The Nutritive Analysis:}

The mechanist sub models as published by Russell et al (1992) was applied on the experimental rations to predict microbial growth from their carbohydrate and protein fractions and their digestion and passage rate using the net carbohydrate and protein system (CNCPS) programmed version 3.0.

\section{Statistical Analysis:}

The statistical analysis was performed using the least squares method described by Likelihood programmer of SAS (1994). The obtained data for nutrients digestibility, nutritive value and effective NDF (eNDF) were subjected to one way analysis of variance according to the following model:

$Y_{i j}=\mu+T_{i}+e_{i j}$

Where:

$$
\begin{aligned}
& Y i j=\text { Observation of the tested factor } \\
& \mu=\text { Overall mean } \\
& T_{i}=\text { Treatment effect } \\
& e_{i j}=\text { Error }
\end{aligned}
$$

The data of rumen liquor parameters were subjected to two- ways analysis of variance according to the following model:

$Y_{i j k}=\mu+T_{i}+p_{j}+t p_{i j}+e_{i j k}$

Where :

$$
\begin{aligned}
& Y i j=\text { Observation of the tested factor } \\
& \mu=\text { Overall mean } \\
& T_{i}=\text { Treatment effect } \\
& p_{j}=\text { time effect } \\
& \left.t_{i j}=\text { interaction effect of the treatment }\right) \times \text { time } \\
& e_{i j}=\text { Error }
\end{aligned}
$$

The differences among means were carried out according to Duncan's New Multiple Range Test (Duncan, 1955).

\section{RESULTS AND DISCUSSION}

Chemical analysis of concentrate feed mixture (CFM), clover hay $(\mathrm{CH})$ and seaweed (S) which were used in the experimental diets are shown in Table (1). It was clear that, the ingredients were within the normal published ranges (Wiedmeier et al 2001).

The cell wall fraction plants have been implicated as a control mechanism for forage intake by ruminants (Waldo, 1986). Lignin is the major component of the cell wall that is recognized as limiting digestion of the wall polysaccharides in the rumen (Jung and Deetz, 1993). Lignin seems to exert its negative effect on cell wall polysaccharide digestibility by shielding the polysaccharides from enzymatic hydrolysis.

Wheeler (2003) recommended the concentrations of non-fiber carbohydrate (NFC) in lactation diets (\% of diet DM) should not fall bellow 20 
to $25 \%$, or not go above 40 to $45 \%$. Diet should never exceed $44 \%$ NFC or contain less than $25 \%$ total NDF or less than $15 \%$ forage NDF. The starch in dry ground corn is less digestible in the rumen than many other starch sources; therefore, ruminal acid production is lower with dry corn than some other feeds. Balancing dietary carbohydrates for maximum energy intake, while supplying adequate fiber for rumen health, is an art as much as a science. While starch is the major non structural carbohydrate (NSC), the energy contribution from structural carbohydrates can be (and should be) significant (Nocek and Russell, 1988). They developed the rumen available carbohydrate (RAC) equation to account for both structural and nonstructural carbohydrate digestion in the rumen. Formulation of rations based on NDF, although achieving one of the most important objectives of ration balancing, which is to define the upper limit for the forage : concentrate $(F: C)$, does not account for the more subtle differences in fiber that are associated with the kinetics of digestion and passage or with physical characteristics (Mertens, 1994).

Table (1): Chemical composition of the ingredients and experimental rations.

\begin{tabular}{|c|c|c|c|c|c|c|c|c|c|c|c|c|c|}
\hline \multirow[b]{2}{*}{ Item } & \multirow[b]{2}{*}{ DM } & \multicolumn{12}{|c|}{ Chemical composition (\% as DM) } \\
\hline & & OM & CP & EE & CF & NFE & Ash & NDF & ADF & Hemi & icellu & ADL & NFC* \\
\hline \multicolumn{14}{|c|}{ Ingredients } \\
\hline $\begin{array}{l}\text { Concentrate } \\
\text { feed mixture } \\
\text { (CFM) }\end{array}$ & 90.86 & 93.07 & 16.54 & 2.14 & 15.17 & 59.22 & 6.93 & 40.34 & 17.58 & 22.76 & 10.00 & 7.58 & 34.05 \\
\hline Clover hay (CH) & 88.89 & 87.71 & 16.61 & 2.29 & 27.76 & 41.03 & 12.29 & 53.29 & 29.58 & 23.71 & 13.96 & 15.62 & 15.52 \\
\hline Seaweed (S) & 88.00 & \begin{tabular}{|l|l|}
75.00 \\
\end{tabular} & 6.80 & 2.30 & 6.80 & 59.10 & 25.00 & 36.52 & 20.06 & 16.46 & 15.72 & 4.34 & 29.38 \\
\hline \multicolumn{14}{|c|}{ Experimental rations } \\
\hline R1 & 93.92 & \begin{tabular}{|c|}
92.10 \\
\end{tabular} & 16.55 & 2.17 & 17.45 & 55.93 & 7.90 & 42.68 & 19.75 & 22.93 & 10.71 & \begin{tabular}{|l|}
9.04 \\
\end{tabular} & 30.70 \\
\hline $\mathbf{R 2}$ & 93.75 & 92.02 & 16.51 & 2.17 & 17.40 & 55.94 & 6.25 & 42.65 & 19.75 & 22.90 & 10.73 & \begin{tabular}{|l|}
9.02 \\
\end{tabular} & 30.70 \\
\hline R3 & 93.72 & \begin{tabular}{|c|}
91.96 \\
\end{tabular} & 16.47 & 2.17 & 17.36 & 55.96 & 6.28 & 42.64 & 19.76 & 22.88 & 10.76 & 9.00 & 30.68 \\
\hline $\begin{array}{l}\text { R1: (ration 1): } \\
\mathrm{CH}+0.40 \% \mathrm{~S}\end{array}$ & & & & & & & & (ratior & (n): 8 & $81.55^{\circ}$ & $\%$ CFI & $\overline{M+18}$ & $8.05 \%$ \\
\hline
\end{tabular}

Table (2) showed the effect of feeding the experimental rations on average daily dry matter intake. The total daily dry matter intake was as\% body weight (BW) 2.54, 2.52 and 2.59 when feeding on R1, R2 and R3, respectively. The average daily intake of CFM was ranged from 2.06 and $2.11 \% \mathrm{BW}$. The $\mathrm{CH}$ was about $0.45 \% \mathrm{BW}$. Rapidly growing cattle, such as steers can be safely fed up to 2.0 to $2.25 \%$ of their weight in concentrates. Feeding roughage at least 1.8 to $2.2 \mathrm{~kg}$ of hay daily. However neither should be fed at over $20 \%$ of the diet (Schreder, 2002).

The voluntary intake of feed depends essentially on the rate of degradation of its digestible matter into particles of a size small enough to enable their passage from the reticulo-rumen to the lower gut. This degradation is achieved by means of the microbial fermentations which takes place in the reticulo-rumen. The cell wall content and the magnitude and 
nature of lignifications of these cell walls are amongst the most important factors which govern the digestibility and the rate of passage of forage (Preston and Leng, 1987).

Table (2): Average daily dry matter intake of concentrate, clover hay and seaweed by Friesian steers during the digestion trials.

\begin{tabular}{|c|c|c|c|}
\hline Items & R1 & R 2 & R 3 \\
\hline Average body weight (kg) & 393 & 396 & 388 \\
\hline Concentrate : Roughage & $81.8: 18.2$ & $81.5: 18.5$ & $81.2: 18.8$ \\
\hline \multicolumn{4}{|c|}{ Intake of DM from : } \\
\hline \multicolumn{4}{|c|}{ Concentrate feed mixture (CFM) : } \\
\hline $\mathrm{Kg} / \mathrm{h} / \mathrm{d}$ & 8.18 & 8.18 & 8.18 \\
\hline As \% BW & 2.08 & 2.06 & 2.11 \\
\hline \multicolumn{4}{|l|}{ Clover hay : } \\
\hline $\mathrm{Kg} / \mathrm{h} / \mathrm{d}$ & 1.81 & 1.81 & 1.80 \\
\hline As \% BW & 0.46 & 0.45 & 0.46 \\
\hline \multicolumn{4}{|l|}{ Seaweed : } \\
\hline $\mathrm{Kg} / \mathrm{h} / \mathrm{d}$ & 0 & 0.04 & 0.09 \\
\hline As \% BW & 0 & 0.01 & 0.02 \\
\hline \multicolumn{4}{|l|}{ Total dry matter intake: } \\
\hline $\mathrm{Kg} / \mathrm{h} / \mathrm{d}$ & 9.99 & 10.03 & 10.07 \\
\hline As \% BW & 2.54 & 2.52 & 2.59 \\
\hline
\end{tabular}

Scott (1990) reported that the Ascohpyllum nodusum contains, as well as some 18 amino acids, 60 minerals and trace elements, kelp meal rich in nitrogen, carbohydrates and also contains considerable amounts of $\beta$ carotene (the precursor of vitamin $A$ ), as well as vitamins $E, D$ and $K$ and some $B$ vitamins. Among the trace elements found in kelp are magnesium, fluorine, manganese, molybdenum, tellurium, thallium, vanadium, tungsten, zinc and zirconium. Deficiencies of these elements are known to cause a variety of disorders in man and animals.

\section{Nutrient Digestibility and Feeding Values of Tested Rations:}

Table (3) shows the nutrient digestion coefficients and feeding values of tested rations. There were no significant effect of feeding the experimental rations on the digestion coefficients of all nutrients and feeding values. But the digestion coefficient of OM, NFE, ADF, cellulose, ADL, NFC, TDN\%, ME (Mcal $/ \mathrm{kg})$ and NE (Mcal $/ \mathrm{kg})$ were slightly higher when feeding on $\mathrm{R} 2$ or R3 than R1.

Aga et al (2000) were used calcified seaweed to study the effect of buffer on $\mathrm{pH}$ and microbial metabolism in continuous culture of rumen contents. They found that there no differences $(p<0.05)$ among treatments were observed for digestion of DM, OM, CP, NDF or ADF.

On the other hand, the kelp meal contains, as well as some 18 amino acids, 60 minerals and trace elements (Scott, 1990). Biologists believe that the amino acids, when absorbed by the animal's rumen, enhance the microbial action within the rumen and hence increase the total digestible nutrients (TDN) available from the test of the feed.

The basic reason for the use of organic forms of trace minerals is the reported increased bioavailability of organic vs. inorganic source of the mineral (Clark et al, 1993). 
Table(3): Effect of feeding the experimental rations on the digestion coefficients and feeding values by Friesian steers.

\begin{tabular}{|c|c|c|c|c|c|}
\hline Items & R 1 & R 2 & R 3 & \pm SEM & $p$ \\
\hline \multicolumn{6}{|c|}{ Nutrient digestibility (\%): } \\
\hline DM & 88.31 & 87.73 & 90.36 & 1.37 & 0.421 \\
\hline OM & 89.95 & 90.39 & 92.30 & 1.61 & 0.5819 \\
\hline $\mathbf{C P}$ & 87.55 & 86.84 & 89.54 & 1.35 & 0.3988 \\
\hline EE & 98.39 & 94.24 & 92.52 & 2.52 & 0.3109 \\
\hline CF & 90.41 & 84.60 & 88.94 & 2.03 & 0.1916 \\
\hline NFE & 89.14 & 92.42 & 93.34 & 1.93 & 0.3408 \\
\hline NDF & 85.86 & 84.24 & 87.82 & 2.41 & 0.5995 \\
\hline ADF & 77.30 & 78.76 & 84.50 & 2.06 & 0.1037 \\
\hline Hemi. & 93.24 & 88.91 & 90.68 & 3.12 & 0.6378 \\
\hline Cell. & 95.66 & 96.99 & 98.95 & 0.87 & 0.0959 \\
\hline ADL & 55.51 & 57.04 & 67.21 & 4.51 & 0.2176 \\
\hline NFC & 94.43 & 99.41 & 98.52 & 1.57 & 0.1366 \\
\hline \multicolumn{6}{|c|}{ Feeding value (\%) } \\
\hline TDN & 84.93 & 85.36 & 86.93 & 1.61 & 0.6707 \\
\hline DCP & 14.49 & 14.34 & 14.74 & 0.22 & 0.4749 \\
\hline ME(Mcal/kg) & 12.64 & 12.70 & 12.94 & 0.23 & 0.6641 \\
\hline $\mathrm{ME}(\mathrm{Mj} / \mathrm{Kg})$ & 3.02 & 3.04 & 3.09 & 0.05 & 0.7082 \\
\hline $\mathrm{NE}(\mathrm{Mcal} / \mathrm{Kg})$ & 1.96 & 1.97 & 2.01 & 0.03 & 0.6835 \\
\hline DDM\%" & 78.06 & 77.57 & 79.89 & 1.21 & 0.4178 \\
\hline RFV $^{\min }$ & 153.7 & 152.2 & 161.1 & 3.82 & 0.2919 \\
\hline
\end{tabular}

* NE (Mcal $/ \mathrm{kg})=($ TDN\% $\times 0.0245)-0.12$ (NRC, 2001)

** DDM\% of DM = 88.9- $0.779 \times$ (ADF\% of DM) (Schroeder , 1996)

*** RFV = DMI x DDM / 1.29 (Schroeder , 1996)

Both the macro and microelements affect the processes that proceed in the animal's organism in the different way and through their presence in the digestion tract. Thus, for example, cellulose degradation in suspension of rumen bacteria cells is accelerated by the following elements : $\mathrm{P}, \mathrm{Mg}, \mathrm{Ca}, \mathrm{K}$, $\mathrm{Na}, \mathrm{Fe}, \mathrm{Mn}, \mathrm{Co}$, and Mo (Durand and Kawashima, 1980).

Table (4) showed that there were no significant effect when feeding the experimental rations on the $(\mathrm{BC})$ of the ruminal liquor at different times of sampling from $0 \mathrm{hr}$ up to $8 \mathrm{hr}$ of feeding. The mean values of $\mathrm{BC}$ was 8.83 , 9.17 and $9.27 \mathrm{ml} \mathrm{eq} / 100 \mathrm{ml} \mathrm{RL}$ for $\mathrm{R} 1, \mathrm{R} 2$ and $\mathrm{R} 3$ respectively. There was no significant effect of the experimental rations on the $\mathrm{pH}$ of the rumen liquor at different times of sampling from $0 \mathrm{hr}$ up to $8 \mathrm{hr}$ of feeding, although the $\mathrm{pH}$ tended to decrease after $8 \mathrm{hrs}$ after feeding on R1, while it was decreased after $4 \mathrm{hrs}$ after feeding on R2 or R3. The mean values were 7.3, 7.3 and 7.35 for $\mathrm{R} 1, \mathrm{R} 2$ and $\mathrm{R} 3$, respectively.

The results also showed that there was no significant effect on the VFA of the ruminal liquor at different times of sampling from $0 \mathrm{hr}$ up to $8 \mathrm{hr}$ of feeding on R1, R2 and R3. The mean values were 9.95, 10.47 and 9.78 $\mathrm{eq} / 100 \mathrm{ml} \mathrm{RL}$ when feeding on $\mathrm{R} 1, \mathrm{R} 2$ and $\mathrm{R} 3$, respectively.

Table (4) showed that there was significant effect of feeding the experimental rations on the $\mathrm{NH}_{3}-\mathrm{N}$ concentration in the rumen at different times of sampling. The $\mathrm{NH}_{3}-\mathrm{N}$ concentration was higher $(\mathrm{p}<0.05)$ at $0 \mathrm{hr}$ when feeding on R2 than R1 or R3 and R1 was higher $(p<0.05)$ than R3, and then $\mathrm{NH}_{3}-\mathrm{N}$ values were higher $(p<0.05)$ when feeding on $\mathrm{R} 1$ or $\mathrm{R} 2$ than $\mathrm{R} 3$ from $2 \mathrm{hr}$ up to $4 \mathrm{hr}$ after feeding. The $\mathrm{NH}_{3}-\mathrm{N}$ concentration tended to 
increased $(p<0.05)$ when feeding on $\mathrm{R} 1$ or $\mathrm{R} 3$ than $\mathrm{R} 2$, but the $\mathrm{NH}_{3}-\mathrm{N}$ concentration was higher $(p<0.05)$ when feeding on R3 than R1 after 8 hrs of feeding. The mean values were higher $(p<0.05)$ when feeding on R2 or R3 (13.74 and $14.20 \mathrm{mg} / 100 \mathrm{ml} \mathrm{RL}$ respectively), than $\mathrm{R} 1(11.82 \mathrm{mg} / 100 \mathrm{ml}$ $\mathrm{RL})$.

As shown in table (4) there was no significant effect on the eNDF values. The values for eNDF were $44.1,44.06$ and $45.42 \%$ when feeding on $\mathrm{R} 1, \mathrm{R} 2$ and $\mathrm{R} 3$ respectively.

Westwood and Lean (2001) reported that rumen $\mathrm{pH}$ fluctuates throughout the day depending on diet, time of feeding of concentrates and the supplementation of fiber sources such as hay. Daily mean ruminal $\mathrm{pH}$ will not adequately represent the highly variable characteristics of ruminal $\mathrm{pH}$. The nadir of rumen $\mathrm{pH}$ when feeding concentrates separately from forages is between tow and four hours after feeding (Kolver and Veth , 2002), with optimal pH being above 5.8 (Kolver, 1998) to 6.0 (Van Soest, 1994) for fiber digestion.

As shown in table (4) the $\mathrm{pH}$ value did not decreased than 7.3, because the samples of ruminal fluid token by stomach tube have a higher $\mathrm{pH}$ than there optimal through a rumen canula (Erdman, 1988). Because cattle fed forage secrete more saliva and have a higher ruminal $\mathrm{pH}$ than cattle fed grain. The impact of fiber on ruminal $\mathrm{pH}$ is explained by its effect on fluid dilution rate. When cattle are fed forage, ruminant and saliva flow are stimulated, the fluid dilution rate is high (as high as $20 \%$ per h), and the large amounts of acid are washed out the rumen to the abomasums where the $\mathrm{pH}$ is lower, a greater fraction of the acid is undissociated and the absorption rate is faster (Crichlow and Chaplin, 1985).

Table (4): Effect of feeding experimental rations on some rumen liquor parameters at different times after feeding.

\begin{tabular}{|c|c|c|c|c|c|c|}
\hline tems & & Ration 1 & Ration 2 & Ration 3 & +SEM & $p$ \\
\hline \begin{tabular}{|l|} 
Parameters \\
\end{tabular} & Hours & Ration I & nation 2 & nations & \pm ェكCIVI & \\
\hline & 0 & 7.78 & 7.69 & 7.79 & & \\
\hline & 2 & 7.36 & 7.52 & 7.34 & & \\
\hline pH-Values & 4 & 7.08 & 6.91 & 7.01 & 0.102 & 0.2850 \\
\hline & 8 & 6.94 & 7.03 & 7.25 & & \\
\hline & Means & 7.29 & 7.29 & 7.35 & 0.051 & 0.6656 \\
\hline & 0 & 10.23 & 11.7 & 10.77 & & \\
\hline & 2 & 9.10 & 8.30 & 9.20 & & \\
\hline Buffering capacity BC & 4 & 7.97 & 8.16 & 8.67 & 0.394 & 0.1686 \\
\hline$(\mathrm{ml} \mathrm{eq} / 100 \mathrm{ml})$ & 8 & 8.03 & 8.50 & 8.44 & & \\
\hline & Means & 8.83 & 9.17 & 9.27 & 0.196 & 0.2821 \\
\hline & 0 & 7.28 & 8.10 & 8.32 & & \\
\hline & 2 & 11.46 & 11.43 & 12.23 & & \\
\hline Total VFA's & 4 & 10.57 & 10.65 & 9.45 & 1.488 & 0.9245 \\
\hline & 8 & 10.48 & 11.68 & 9.13 & & \\
\hline & Means & 9.95 & 10.47 & 9.78 & 0.944 & 0.7964 \\
\hline & 0 & 11.00 & 13.31 & 9.30 & & \\
\hline & 2 & 13.25 & 15.38 & 14.49 & & \\
\hline $\mathrm{NH}_{3}-\mathrm{N}(\mathrm{mg} / 100 \mathrm{ml})$ & 4 & 8.77 & 13.05 & 13.42 & 0.935 & 0.0003 \\
\hline & 8 & 14.27 & 13.21 & 19.61 & & \\
\hline & Means & 11.82 & 13.74 & 14.20 & 0.467 & 0.0034 \\
\hline$\%$ eNDF* & & 44.10 & 44.06 & 45.42 & 1.23 & 0.6911 \\
\hline
\end{tabular}

a, b and c : Means within the same raw with different superscripts are significantly different $(\mathrm{P}<0.05)$.

* \% eNDF $=($ pH -5.425$) / 0.04229$ (Fox et al., 2000) 
On the other hand, Van Soest, (1994) reported that Lucerne hay provides greater buffering capacity compared to Bermuda grass hay for several reasons. First, Lucerne contains higher levels of protein and calcium, both which buffer gastric acid. Also, Lucerne fiber has a higher cation exchange capacity compared to graminaceous plants due largely to its higher content of lignin and other polyphenotics.

Generally, Bramly ,2004) showed that the cow was consistent with acidosis, being characterized by high concentration of valerate and propionate and low concentrations of ammonia.

The specific attributes of fibrous components in the forage that contribute most to its function as roughage are comprised in the term " effective fiber ", specifically effective neutral detergent fiber or eNDF. This term describes the properties of forage that stimulate chewing, regurgitation on rumination. The eNDF of forage not only represents its particular functionally in promoting digestive function, but also represents the character of the forage that can limit energy intake, and thus have a negative influence on performance (Jeffries, 1990).

Table (5): Effect of experimental ration on sugar and starch fermentation $(g / d)$, total microbial protein $(g / d)$ and total amino acids (AA) \% of requirement.

\begin{tabular}{|l|c|c|c|}
\hline Item & R1 & R2 & R3 \\
\hline Sugar fermentation $(\mathrm{g} / \mathrm{d})$ & 276.6 & 277 & 277.6 \\
\hline Starch fermentation (g/d) & 729.4 & 731.4 & 737.2 \\
\hline Total microbial protein $(\mathrm{g} / \mathrm{d})$ & 1006 & 1008.4 & 1014.8 \\
\hline Total AA \% of requirement & 77.61 & 76.65 & 77.98 \\
\hline
\end{tabular}

In general as shown in Table (5) the predicted values using CNCPS showed that, the sugar, starch and total microbial protein were tended to increase when feeding on R2 or R3 than R1. The total amino acids \% of the requirement were $77.61,76.65$ and 77.98 when was feeding on $\mathrm{R} 1, \mathrm{R} 2$ and $\mathrm{R} 3$, respectively.

The presented study, may lead to concluded that the seaweed supplementation may enhance the immune response, but more information is needed on its mode of action and method of administration. The total VFA was higher with feeding on $81.55 \% \mathrm{CFM}+18.05 \% \mathrm{CH}+0.40 \%$ seaweed (S) than the other rations.

\section{REFERENCES}

Aga, L. M.; Koski, R. J. and Stern, M. D. (2000). Effect of buffers on pH and microbial metabolism in continuous culture of rumen contents. $25^{\text {th }}$ conference on rumen function, Chicago, Illinois.

AOAC (1990). Association of Official Analytical Chemists. Official Methods of Analysis. 15th Ed., Washington DC .

Bramly, E. (2004). Ruminal acidosis in Southern Australian dairy cattle. Ph D thesis, University of Sydney. 
Britton, R. A. and Stock, R. A. (1986). Acidosis, rate of starch digestion and intake. In : Symposium proceedings : Feed intake by beef cattle. Oklahoma State University. Pp.125.

Calsamiglia, S.; Stern M.D. and Firkins, J.L. (1995). Effects of protein source on nitrogen metabolism in continuous culture and intestinal digestion in vitro. J. Anim. Sci., 73: 1819.

Clark, T. W.; Xin Z.; Du Z. and Hemken, R. W. (1993). A field trial comparing copper sulfate, copper proteinate and copper oxide as copper sources for beef cattle. J. Dairy Sci. 76 (suppl.) : 334.

Conway, E.F. (1957). Microdiffusion Analysis and Volumetric Error. Rev. Ed. Lock wood, London.

Cooper, R. and Klopfenstein, M. (1996). Effect of rumensin and feed intake variation on ruminal $\mathrm{pH}$. In : Scientific update on rumensin / Tylan / Micotil for the professional feedlot consultant. Elanco animal health, Indianapolis, IN. Pp A-1.

Coppock, C. E.; Schelling, G. T.; Byers, F. M.; West, J. W. and Labore, J. M. (1986). A naturally occurring mineral as a buffer in the diet of lactating dairy cows. J. Dairy Sci. 69: 111.

Crichlow, E. C. and Chaplin, R. K. (1985). Ruminal lactic acidosis : Relationship of fore stomach motility to nondissociated volatile fatty acids levels.

Duncan, D.B. (1955). Multiple Range and Multiple F Test. Biometrics, 11:10.

Durand, M. and Kawashima, R. (1980). Influence of minerals in rumen microbial digestion. W : Ruckebush Y., Thivend P. (ed.) Digestive physiology and metabolism in ruminants. Avi. Publ. Company, Inc. Westport, CT. 375.

Erdman, R. A. (1988). Dietary buffering requirements of the lactating dairy cow. A Review. J. Dairy Sci. $71: 3246$.

Fox, D. G. ; Tylutki, T. P.;. Van Amburgh, M. E; Chase, L. E.; Pell, A. N.; Overton, T. R.; Tedeschi, L. O.; Rasmussen, C. N. and Durbal, V. M. (2000). The net carbohydrate and protein system for evaluating herd nutrition and nutrient excretion. Animal Science Mimeo 213, Department of animal science, Cornell university, 130 Morrison Hall, Ithaca, New York, 14853.

Ghoneim, A. (1967). Animal Nutrition, Principles and Feeding-stuffs, $2^{\text {nd }}$ Edt. Anglo.. Egyptian Library, University. (Arabic Text Book).

Glock, R. D. and DeGroot,B. D. (1998). Sudden desth of feedlot cattle. J. Anim. Sci. $76: 315$.

Hristov, A. N.; Ivan, M.; Rode, L. M. and McAllister, T. A. (2001). Fermentation characteristics and ruminal ciliate protozoa papulations in cattle fed medium - or - high concentrate barley -based diets. J. Anim. Sci. $79: 515$.

Hunter, R. D.; Drouillard, J. S. and Titgemeyer, E. C. (1999). Effect of level of non-enzymatically browned soybean meal in limited fed, grain sorghum diets for growing fibers. Kansas State University, Agricultural Experiment Station and Cooperative Extension Service. 
Huntington, G. B. (1988). Acidosis. In : The ruminant animal-digestive physiology and nutrition. Editor D. C. Church, Prentice Hall, Englewood Cliffs, New Jersey. P. 474.

Jeffries, T. W. (1990). Biodegradation of lignin-carbohydrate complexes. Biodegradation 1. 163.

Jung, H.G. and Deetz D.A. (1993). Cell wall lignification and degradability. In: J.G. Jung, D.R. Buxton, R.D. Hatfield and J. Ralph (Ed.) Forage Cell Wall Structure and Digestibility. p. 315. ASA-CSSA-SSSA, Madison, WI.

Kolver, E. S. (1998).Digestion of pasture by dairy cows. Proceeding of the $15^{\text {th }}$ annual seminar of the society of dairy cattle veterinarians of the New Zealand veterinary Association.

Kolver, E. S. and De Veth, M. J. (2002). Prediction of ruminal pH from pasture-based diets. J. Dairy Sci. $85: 1255$.

Mertens, D. R. (1994). Regulation of forage quality, page 450 in forage quality, evaluation and utilization. G. C. Fahey, Jr., ed. Am. Soc. Agron., Madison, WI.

Nickolson, J.W.G.; Cunningham, M.M. and Friend, D.W. (1963). The addition of buffers to ruminant rations. 4- The effect of additions of sodium bicarbonate, sodium propionate, limestone and cod liver oil on inter rumen environment. Canadian J. Anim. Sci., 42: 309.

Nocek, J.E. and J.B. Russell (1988). Protein and energy as an integrated system, relationship of ruminal protein and carbohydrate availability to microbial synthesis and milk production. J. Dairy Sci. $71: 2070$.

NRC ( National Research Council ) (2001). Nutrient Requirements of Dairy Cattle, $7^{\text {th }}$ rev. ed. National Academy Sci., Washington, DC.

Preston, T. R. and Leng, R. A. (1987). Matching ruminant production systems with available resources in the tropics and sub-tropics. Penambul Books : Armidale Australia, pp 245.

Russell, J. B. and Hino, T. (1985). Regulation of lactate production in streptococcus bovis : a spiraling effect that contributes to rumen acidosis. J. Dairy Sci. $68: 1712$.

Russell, J. B.; O'conner, J. D.; Fox, D. G. and Van Soest, P. J. (1992). A net carbohydrate and protein system for evaluating cattle diets. 1. Ruminal fermentation. . J. Anim. Sci., 70: 3551.

SAS (1994). SAS / STAT R User's Guide : Statistics. Ver. 6.04, Fourth Edition, SAS Institute Inc, Cary, NC.

Schneider, B.H. and Flatt, W.P. (1975). The evaluation of feeds through digestibility experiments. The university of Georgia Press Athens 30602.

Schreder, P. (2002). Feeding \& Riparian the show steer. OUS \& Riparian, Linn / Benton / Lan Countries No. L \& R.

Schroeder, J.W. (1996). Quality forage for maximum production and return . NDSU Extension service, North Dakota State University .

Scott, C. (1990). Kelp Help : Livestock thrive on seaweed. Elphin, Lanark Country, Eastern Ontario, Canada. 
Solorzano, L. C.; Armentano, L. E.; Grummer, R. R. and Dentine, M. R. (1989). Effect of sodium bicarbonate or sodium sesquicarbonate on lactating Holsteins fed a high grain diet. J. Dairy Sci. 72 : 453.

Sykes, B. (2009). Seaweed and probiotics. Langcliffe Road, Settle, North Yorhshire.

Van Keulen, J. and Young B.A. (1977). Evaluation of acid insoluble ash as a natural marker in ruminant digestibility studies. J.Anim. Sci., 44: 282.

Van Soest, P. J. (1994). Nutritional Ecology of the ruminant. New York, Cornell University press.

Van Soest, P. J. (1982). Nutritional Ecology of the Ruminant. O \& B Books Inc., Corvallis, Oregon, USA, pp 1.

Waldo, D.R. (1986). Effect of forage quality on intake and concentrate interactions. J. Dairy Sci., $69: 617$.

Warner, A.C.I. (1964). Production of volatile fatty acids in the rumen, methods of measurements.Nutr. Abst.\& Rev., 34. 339.

Westwood, C. T. and Lean L. J. (2001). Nutrition and lameness in pasture-fed dairy cattle. Proceedings of the New Zealand Society of Animal Production 61: 1.

Wheeler, B. (2003). Guidelines for feeding dairy cows. Ministry of Agriculture and Food, Government of Ontario, Canada .

Wiedmeier, R. D.; Zobell, D. R. and Burrell, C. (2001). Feeding and supplementation of low-quality forage as an alternative for wintering beef cows. Department of Animal Dairy and Veterinary Science, Utah State University.

Zinn, R. A. (1991). Comparative feeding value of steam - flaked corn and sorghum in finishing diets supplemented with or without sodium bicarbonate. J. Anim. Sci. 69: 905.

$$
\begin{aligned}
& \text { تأثثير إضـافة الطحالب البحريـة لعلائق تسـين عجول الفريزيـان على : 1- القيمـة }
\end{aligned}
$$

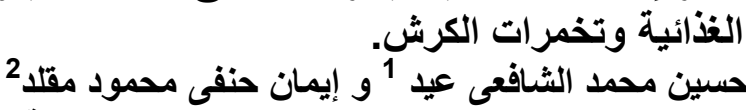

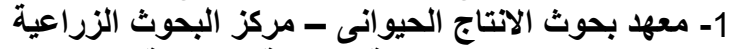

$$
\begin{aligned}
& \text { 2- قسم إنتاج الحيوان - كلية الزراعة - جامعة الئمة المنصورة النزاعة }
\end{aligned}
$$

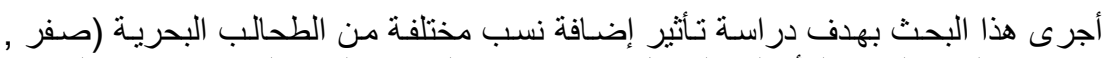

$$
\begin{aligned}
& \text { 0,4, 0,9) من المادة الجافة المأكولة على كل من معاملات الهضم و القيمة الغذائية وبعض المرية المعايير , } \\
& \text { وتم تكوين ثلاث علائق على النحو التالى: }
\end{aligned}
$$

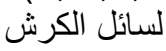

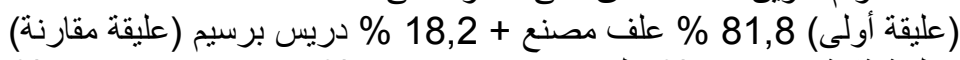

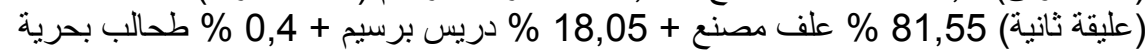

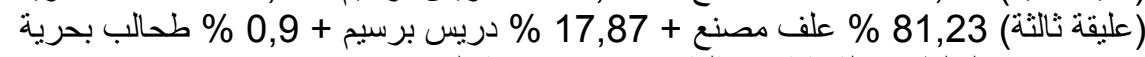

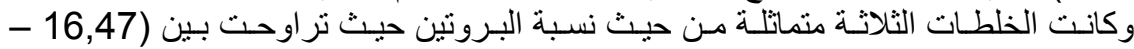

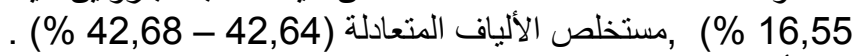

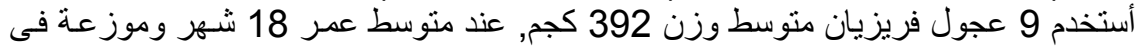

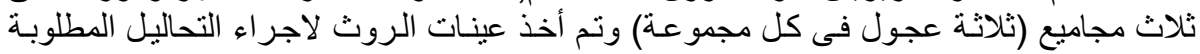




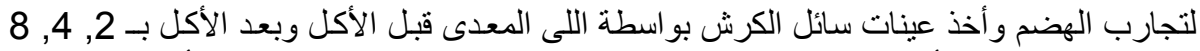
ساعات لتقدير تركيز أيون الهيدروجين ( pH ) , السعة التنظيمية للكرش , تركيز الأحماض الدئل الدهنية

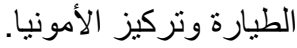

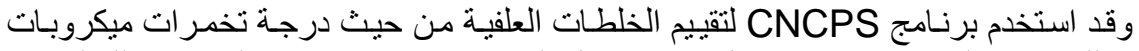

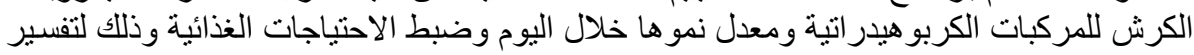

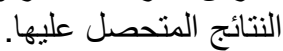

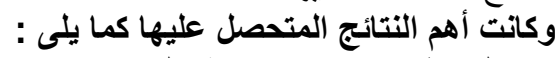

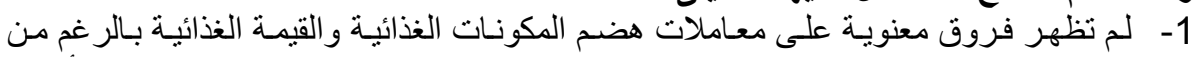

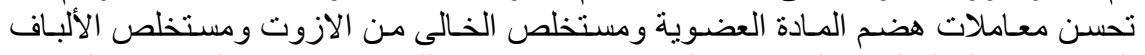

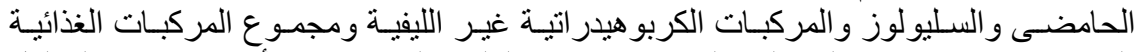

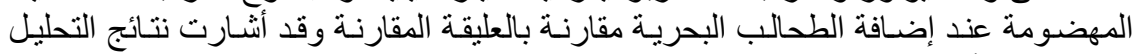

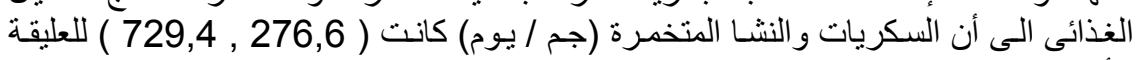

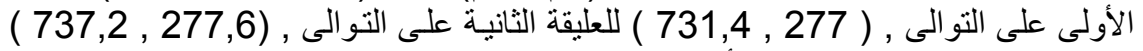

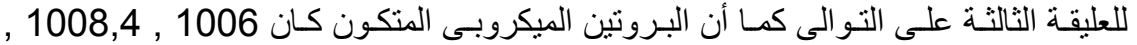

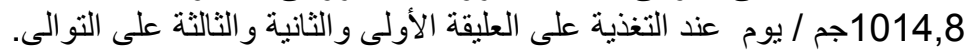

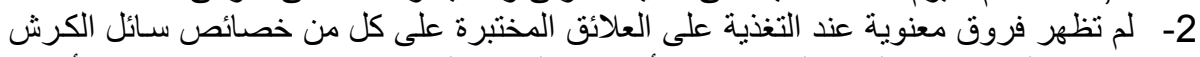

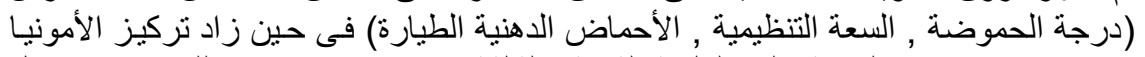

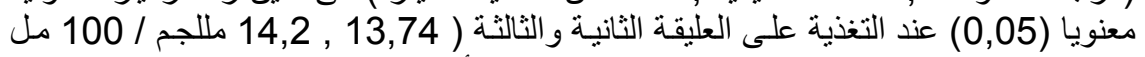
سائل كرش) على التو الى مقارنة بالتغذية على العليقة الأولى (11,82 ملنى ملنم / 100 مل سائل

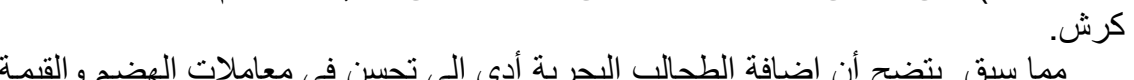

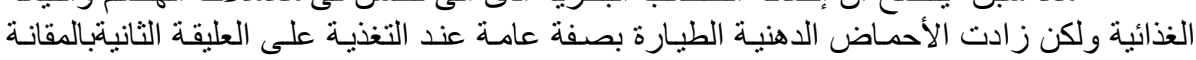
بالتغذية على العلائق الأخرى.

كلية الزراعة - جامعة المنصورة اكاديمية البحث العلمى

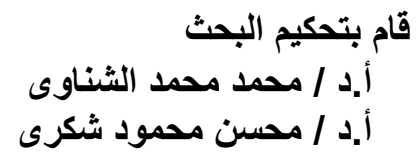

